\title{
Correction to: Constructing and validating a questionnaire on barriers to EFL learners' reflective writing
}

Fariba Salahi(D) and Majid Farahian * (1)

The original article can be found online at https://doi. org/10.1186/s40862-02100124-3

\section{*Correspondence:}

farahian@iauksh.ac.ir

Department of ELT,

Kermanshah Branch, Islamic

Azad University, Kermanshah,

Iran

\section{Correction to: Asian. J. Second. Foreign. Lang. Educ. (2021) 6:20 \\ https://doi.org/10.1186/s40862-021-00124-3}

Following publication of this article (Salahi \& Farahian, 2021), it is reported this article contained an error. In the Abstract, "reflective writing of Iranian English as a Foreign Language (EFL) teachers", the word "teachers" should be changed to "learners".

The original article has been updated.

Published online: 23 December 2021

\section{Reference}

Salahi, F., \& Farahian, M. (2021). Constructing and validating a questionnaire on barriers to EFL learners' reflective writing. ASian-Pacific Journal of Second and Foreign Language Education, 6, 20. https://doi.org/10.1186/s40862-021-00124-3

\section{Publisher's Note}

Springer Nature remains neutral with regard to jurisdictional claims in published maps and institutional affiliations. author(s) and the source, provide a link to the Creative Commons licence, and indicate if changes were made. The images or other third party material in this article are included in the article's Creative Commons licence, unless indicated otherwise in a credit line to the material. If material is not included in the article's Creative Commons licence and your intended use is not permitted by statutory regulation or exceeds the permitted use, you will need to obtain permission directly from the copyright holder. To view a copy of this licence, visit http:// creativecommons.org/licenses/by/4.0/. 